\title{
Features of the Formation of the Potential of the Labor Force in the Reclamation of the Agro- industrial Complex of Russia
}

\author{
Aleksandra Ugryumova, Lyudmila Pautova*, and Olesya Grishayeva \\ Federal State Budgetary Scientific Institution All-Russian Research Institute of Irrigation and \\ Agricultural Water Supply Systems «Raduga», Kolomna urban district, Raduzhny, Russia
}

\begin{abstract}
The purpose of the study is to define the concept of "labor force potential" for land reclamation and to investigate its structural and functional elements using the example of the human resources potential of the Federal State Budgetary Institution. In the course of the study, the theoretical and methodological foundations of the potential of the labor force were determined, the industry characteristics and the main trends of its formation, development as the main resource for the development of the reclamation industry were identified. Experiment Methods. In the course of the research, the following methods were used: theoretical analysis, mathematical and statistical processing of primary data, systemic, logical and correlation analysis, processing and generalization of research results. In this work, a scientific-practical and system-logical analysis of the structure of personnel of 62 FSBI "Management "Meliovodkhoz", subordinate to the Department of Land Reclamation, of all federal districts has been performed. In particular, the results of scientific and practical analysis of scientific approaches to understanding the potential of the labor force, its structural and functional elements are presented in detail; studying the structure of the staff of the Federal State Budgetary Institution in terms of structural and functional, age, educational and professional growth.
\end{abstract}

\section{Introduction}

In the context of the implementation of the State Program "Development of Agriculture and Regulation of Markets of Agricultural Products, Raw Materials and Food for the Period until 2025" and the Departmental Program "Development of the Land Reclamation Complex of Russia", the issues of studying, identifying and solving the problems of forming the potential of the labor force in the agricultural production sector are relevant.

The following basic directions have been identified as priorities for the development of the social-and-economic potential of land reclamation in the Russian Federation until 2030: [1]:

- increase in irrigated (drained) lands and an enhancement in the reclamation state of soils;

- optimum use of water resources;

- increasing the profitability of agricultural production.

*Corresponding author: cosidanie35@yandex.ru 
Various aspects of assessing the reclamation potential were developed in the works of such domestic scientists as: N.N. Dubenko, G.V. Olgarenko, V.N. Krasnoshchekov, V.V. Melikhov, V.N. Shchedrin et al. However, the available studies of the industry's potential did not focus on the factors driving the growth of land reclamation in the Russian Federation and did not consider these drivers in the context of the country's federal districts.

The most relevant, pursuant to researchers, is to identify and substantiate the conditions that determine the formation and development of the social-and-economic potential of the land reclamation industry of the country in its territorial space. In particular, the formation of the potential of the labor force in the reclamation industry of the agro-industrial complex.

\section{Research Methodology}

Improving the efficiency of using the ameliorative potential of the Russian Federation is one of the most effective ways to increase the efficiency of the entire agricultural complex of the country, contributing to increased food security and import substitution.

Pursuant to researchers, it is human resources, fixed assets of the Federal State Budgetary Institution of the Department of Land Reclamation of the Ministry of Agriculture of the Russian Federation and investments in the land reclamation industry that are its main points of growth that may increase the return on land reclamation work.

Analysis of growth points of the land reclamation industry for 2017-2019 will allow to determine not only the most optimal opportunities for the reclamation industry, but also to identify areas that realize its social-and-economic potential.

Research methods: theoretical and practical analysis, development and systematization of information and analytical materials on the human resources of the industry and fixed assets of the Federal State Budgetary Institutions of the Department of the Ministry of Agriculture, logical and situational analysis, methods of statistical analysis, methods of processing and summarizing the results.

Research stages:

- Detailing the concepts and factors governing the formation and development of the ameliorative potential of the Russian Federation.

- Substantiation of the structure and regulatory support of labor force management in the reclamation industry of the agro-industrial complex.

- Development of recommendations to enhance the efficiency of provision and management of labor for the Federal State Budgetary Institution of the Department of Land Reclamation of the RF Ministry of Agriculture.

The theoretical and methodological features of the formation of the production and personnel potential of the agro-industrial complex of Russia are studied in the works of T.I. Gulyaeva, E.V. Buraeva, Grishayeva O. Yu. [2], M.L. Vartanova [3], A.V. Kozlov [4], I.N. Primyshev, S.G. Cheremisina, S.S. Skaranik [5], Noskova M.V. [6], Khlusov V.N., Khlusova I.A. [7] et al.

Despite the research results of these authors, the concept of "potential of the reclamation workforce" is insufficiently studied and developed in industry research. In order to determine its scientific and methodological basis, content and structural elements, it is advisable to study the category of "labor force potential" in scientific and practical research of other spheres of activity and branches of the agro-industrial complex.

\section{Findings}

Trends and increases in the proportions of the structural parts of the FSBI personnel have been determined. 
Specialized industry risks, dependences between the specific weights of all employees of the FSBI "Management "Meliovodkhoz" and the percentage of these employees trained in the additional vocational education system, in the context of the Federal District of the Russian Federation, were identified.

The absolute and relative indicators of the growth in the number of employees of the FSBI Department of Land Reclamation who were trained in the additional vocational education system in federal districts for 2019 were calculated in comparison with the level of 2018.

On the basis of the results of a scientific and practical study of the features of the potential of the labor force in the land reclamation industry, recommendations for improving the process of forming the personnel potential of the land reclamation of the agro-industrial complex of Russia are determined.

\section{Discussion}

Based on the results of the system-theoretical and scientific-practical analysis of the concept of "labor force potential" [8;9;10], it is advisable to highlight the main trends in its formation and development:

- personal-professional and socio-cultural orientation;

- structural, professional and competence orientation.

The results of the system-logical and theoretical analysis, considering these trends in the formation of the potential of the labor force, make it possible to determine the totality of its main structural and functional elements, Fig. 1.

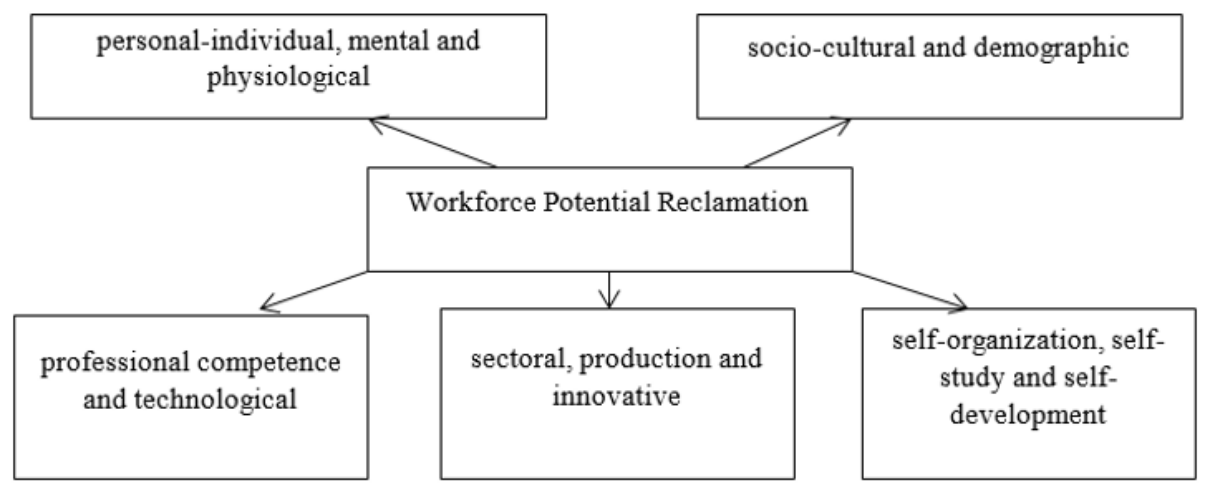

Fig. 1. Structural elements of a reclamation workforce potential

Source: compiled by the authors.

Systematizing and summarizing the results of the theoretical analysis of the concept of "labor force potential" and the factors of its formation, it seems appropriate to highlight a certain set of scientific and methodological approaches at the mega, macro and micro levels of social-and-economic and sectoral interaction (Fig. 2). 
Scientific and methodological foundations for the formation of human resources in the reclamation industrv of the agro-industrial complex

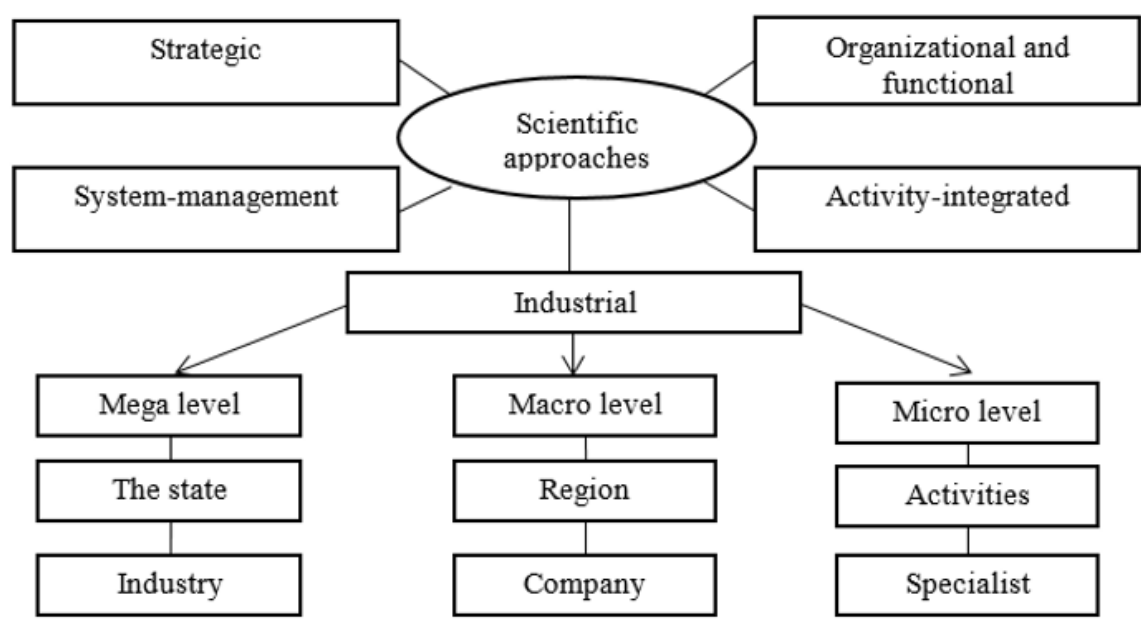

Fig. 2. Scientific and methodological foundations for the formation of the potential of the labor force in the reclamation industry of the agro-industrial complex of Russia.

Source: compiled by the authors.

Summarizing the results of the theoretical analysis of the methodological foundations and approaches to the formation of the potential of the reclamation workforce [9, p. 11-55], it is advisable to conclude that, within the framework of the presented study, the authors consider the production and sectoral approach to be the most productive methodology for developing the potential of the reclamation workforce. This is justified by the fact that within the framework of this approach, the main elements of the potential of the labor force include complex and fairly objective indicators of the professional and industrial activity of a specialist.

The formation of the potential of the labor force of the industry on the basis of the production and sectoral approach, at the macro level determines many factors in the development of the sectoral economy (i.e., the formation of a macrosystem). Thus, e.g., in the branches of the agro-industrial complex, these processes depend on the conditions that Noskova M.V. [6] conditionally aggregates into factors of development of "human potential of animal husbandry" and factors of development of "human potential of crop production". For these main sectors of agriculture, which have completely different organizational and technological tools for functioning, there are similar factors affecting the development of the potential of the labor force:

- general political and economic for the development of the country and specific sectoral;

- demographic, closely related to the factors of social policy of the state, ensuring human health, its suitability for work;

- economic, affecting the productivity and health of employees in the industry;

- sectoral, formed directly considering the peculiarities of the development of the economy of animal husbandry and crop production based on the organizational specifics of the reproduction of products. 


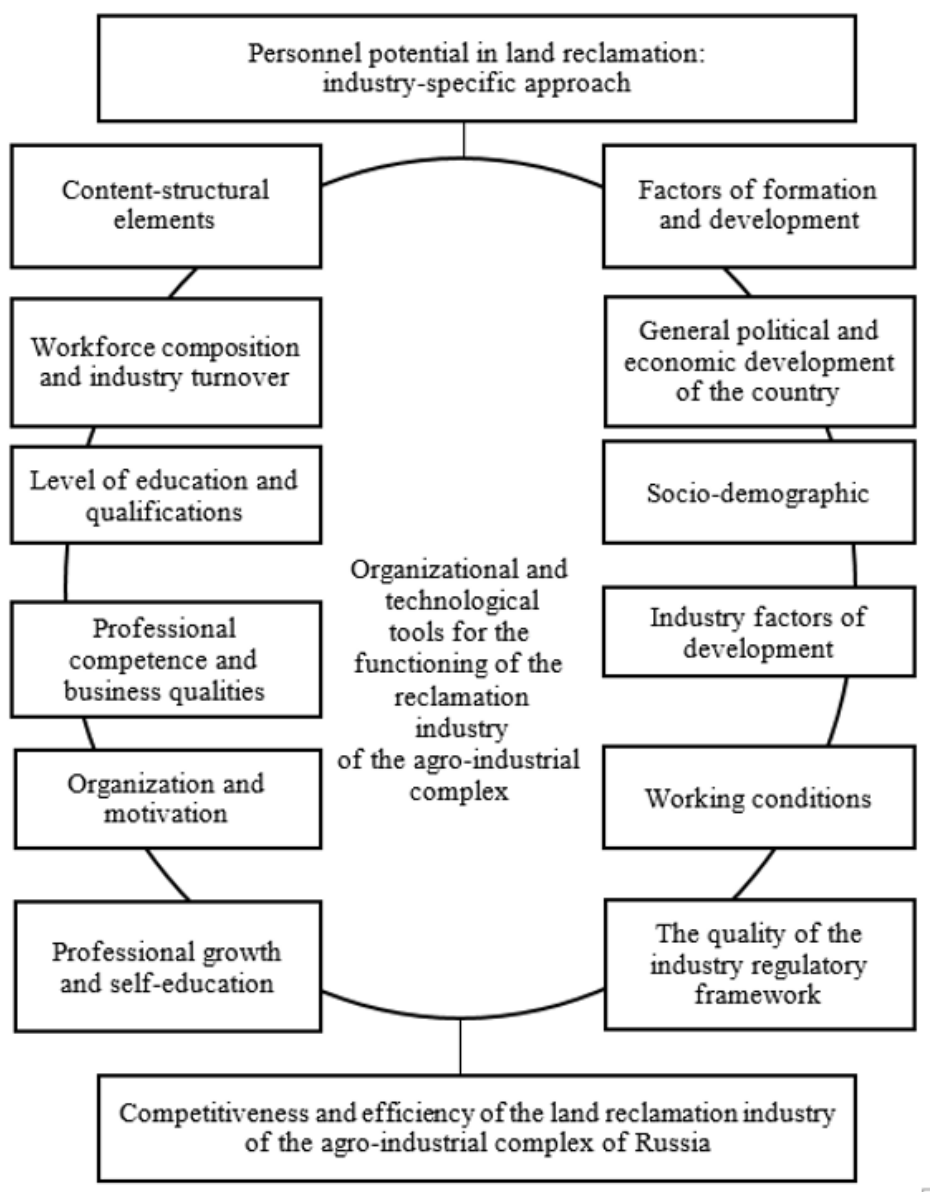

Fig. 3. Formation of the potential of the labor force for land reclamation of the agro-industrial complex based on the production and sectoral approach.

Source: compiled by the authors.

On the basis of this approach, within the framework of this study, an opportunity is provided for scientific and practical study and substantiation of the selected indicators of the personnel potential of the industry, determination of directions for their enhancement in the reclamation industry of the agro-industrial complex.

The authors conducted a study of the potential of the labor force in the Federal State Budgetary Institution "Management "Meliovodkhoz" (hereinafter - the FSBI), subordinate to the Department of Land Reclamation of the Ministry of Agriculture of the Russian Federation for the period 2018-2019 by federal districts. The analysis of the personnel structure of 62 FSBI "Management "Meliovodkhoz" of all federal districts for the period 2015-2019 was performed. The total sample of the study was 44,357 people - the FSBI employees. Based on the data provided by FSBI 63, the following aspects of the labor force were investigated:

- Structural - the number and proportion of groups of employees.

- Age - the age of the employees.

- Educational - the level of education of employees.

- Professional growth - advanced training and retraining for all categories of employees.

The results of a comparative analysis of the number and specific weights of groups of employees considered by the FSBI Department of Land Reclamation by federal districts are 
presented in Tables 1 and 2. For each federal district, they contain, respectively, the range (difference between the maximum and minimum values) of the number (people) and specific weights (\%) of groups of employees of the FSBI Department of Land Reclamation in the district in 2019 and are intended for comparative analysis by federal districts.

Table 1. The scope of the number of employees of the FSBI Department of Land Reclamation by

Federal Districts in 2019.

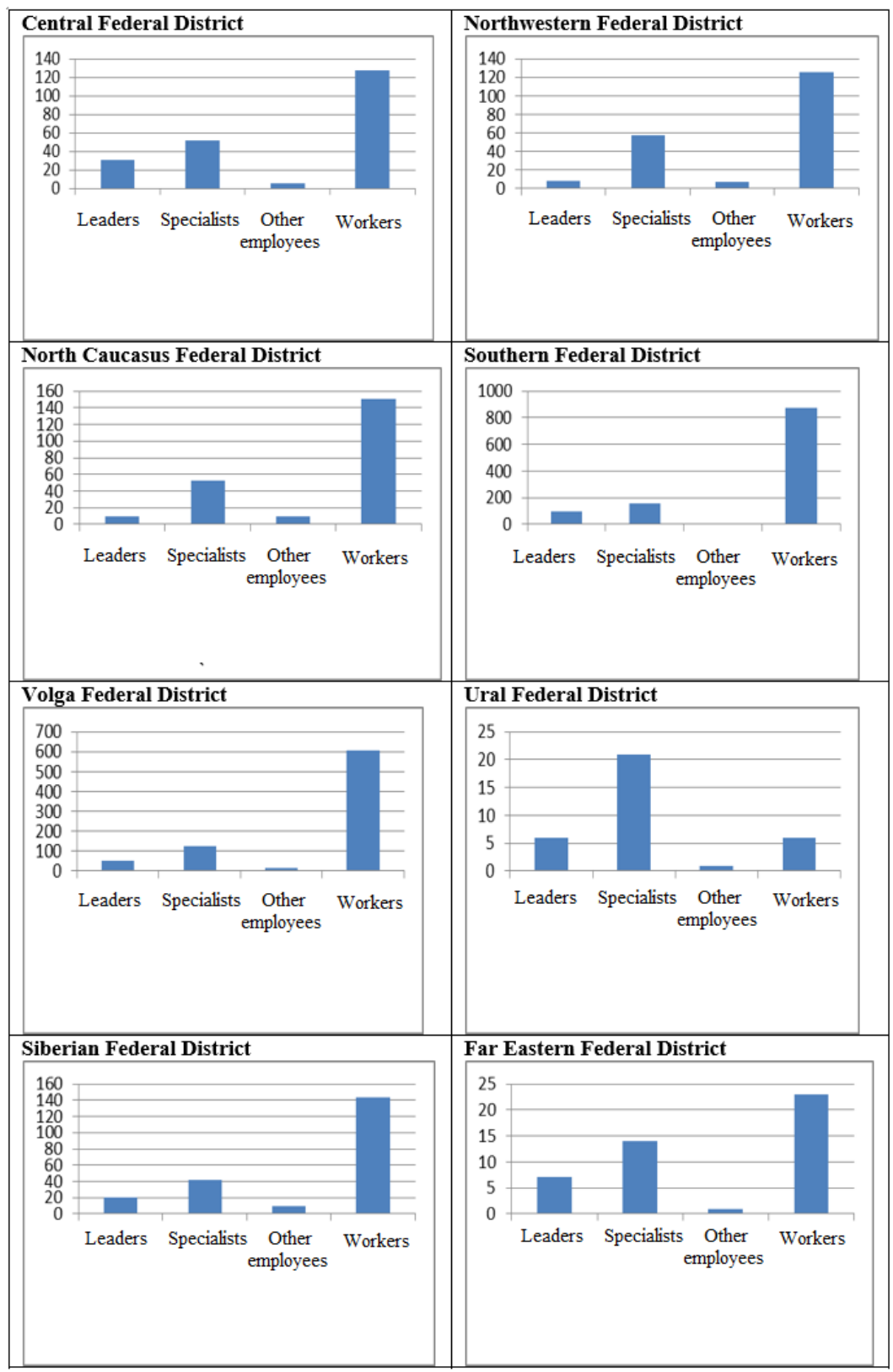

Source: compiled by the authors.

Table 2. The range of the share of groups of employees of the FSBI Department of Land Reclamation by Federal Districts in 2019. 


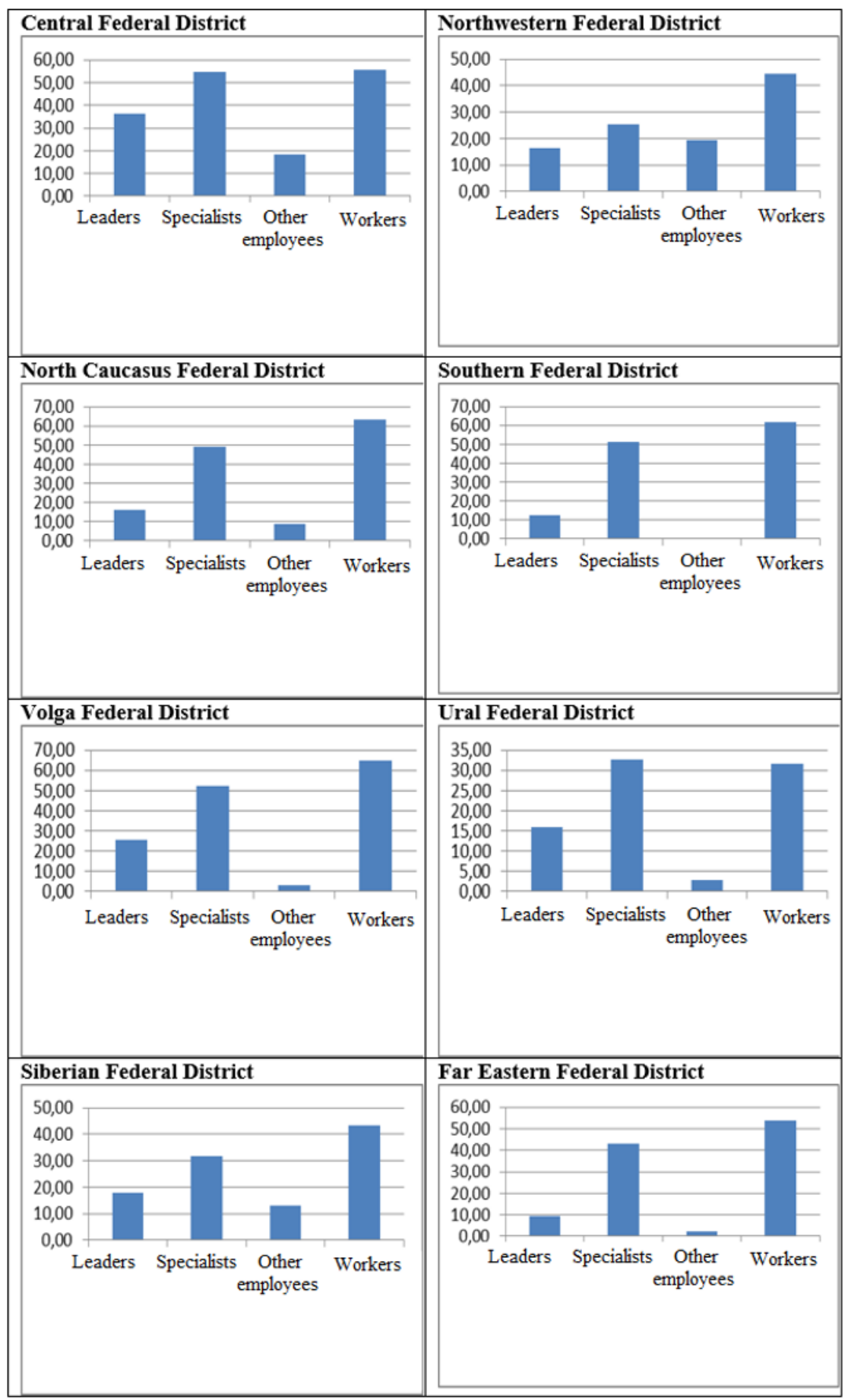

Source: compiled by the authors.

Based on the information presented in Tables 1 and 2, in all FDs, except for Ural Federal District, the greatest heterogeneity in the number of employees was recorded. A significant heterogeneity in the number of managers was observed in the Central Federal District, Ural Federal District and Far Eastern Federal District; and in the group of specialists - in all federal 
districts. The number of other employees turned out to be more homogeneous in all FDs. In all FDs, there was a scatter in the proportions of managers, specialists and employees, which indicates the absence in the industry of a normative approach to the formation of the staffing table in the FSBI.

The results of the analysis of the age structure of the personnel of the FSBI Department of Land Reclamation of the Ministry of Agriculture of the Russian Federation by federal districts for 2018-2019 [9] showed that in 2018-2019 the smallest average share was in the group of employees under the age of 25, and the largest - in the group of employees in the age from 50 to 60 years. Herewith, a tendency for the worsening of the situation in 2019 compared to 2018 was revealed.

Such an unfavorable situation in the industry causes a number of natural negative consequences for the human resources of land reclamation. In particular, after the age of 50, a decrease in working hours is more often observed and the proportion of employees applying for part-time employment is growing (while the labor market is not ready to provide such employment for everyone); obsolescence of knowledge, skills and abilities is recorded, which is not always possible to compensate for continuous learning; "older" employees are also not always ready to invest in additional professional education.

The authors examined the dominant trends in the specific weights of age groups of employees of the FSBI Department of Land Reclamation of the Ministry of Agriculture of the Russian Federation by Federal Districts for 2019, which revealed the following trends:

- staff under 25 increased in the North Caucasus Federal District, Volga Federal District and decreased in the Central Federal District, Northwestern Federal District, Southern Federal District, Ural Federal District and Siberian Federal District;

- staff from 25 to 30 years increased in the Central Federal District, Northwestern Federal District, Siberian Federal District and decreased in the North Caucasus Federal District, Southern Federal District, Volga Federal District, Ural Federal District and Far Eastern Federal District;

- staff from 30 to 40 years increased in the North-West Federal District, North-Western Federal District, Ural Federal District, Siberian Federal District and decreased in the Central Federal District, Southern Federal District, Volga Federal District, Far Eastern Federal District;

- staff from 40 to 50 years increased in the Central Federal District, the Southern Federal District, the Volga Federal District, the Ural Federal District, the Far Eastern Federal District and decreased in the Northwestern Federal District, the North Caucasus Federal District;

- staff from 50 to 60 years increased in the Northwestern Federal District, Ural Federal District, Far Eastern Federal District and decreased in the Central Federal District, North Caucasus Federal District, Southern Federal District, Volga Federal District, Siberian Federal District;

- staff from 60 to 65 years increased in the Central Federal District, North Caucasus Federal District, Southern Federal District, Volga Federal District and decreased in the Northwestern Federal District, Ural Federal District, Siberian Federal District, Far Eastern Federal District; - staff from 65 years old increased in the Central Federal District, Northwestern Federal District, Southern Federal District, Volga Federal District, Far Eastern Federal District and decreased in the North Caucasus Federal District, Ural Federal District, and Siberian Federal District.

Thus, pursuant to the authors, the revealed trend of rejuvenation of industry personnel in groups of up to 20 years, from 20 to 30 years and from 30 to 40 years is insufficient to suspend the process of retirement of professional personnel in the industry.

Based on the analysis, following specialized industry risks were identified:

- an increase in the average age of the sectoral personnel in the reclamation industry, compared with the all-Russian indicators. If the maximum number of employed in the 
Russian Federation (28.1\%) falls on the age group from 30 to 39 years old, then in 20182019. in the reclamation industry, such employees corresponded to the age group 60-64;

- there is a tendency of an increase in the share of employees in older age groups (60-64 years) in the industry and a predominance of vocational training in older age groups (50-59 years), which does not contribute to the effective formation of the labor potential of the industry, since an increase in the share of vocational training of an older age group causes processes in which the amortization of human capital is not replaced by investments that ensure an increase in labor productivity, and a decrease in labor productivity, in turn, leads to a decrease in wages and the life quality of employees in the industry.

The development of the potential of the land reclamation workforce is of primary importance to the professional and educational level and growth of the industry's employees. Therefore, the characteristics of the level of education of the employees of the FSBI under consideration by federal districts will be presented in terms of the proportions of employees with higher, secondary general and secondary vocational education (Tables 10 and 11).

Table 3. The proportions of employees under consideration by the FSBI Department of Land Reclamation who have higher, secondary general and secondary vocational education by federal districts for 2018-2019, \%.

\begin{tabular}{|c|c|c|c|c|c|c|}
\hline \multirow{2}{*}{ FD } & \multicolumn{6}{|c|}{ Education } \\
\cline { 2 - 7 } & \multicolumn{2}{|c|}{ Higher } & \multicolumn{2}{c|}{ secondary } & \multicolumn{2}{c|}{$\begin{array}{c}\text { secondary } \\
\text { professional }\end{array}$} \\
\cline { 2 - 7 } & $\mathbf{2 0 1 8}$ & $\mathbf{2 0 1 9}$ & $\mathbf{2 0 1 8}$ & $\mathbf{2 0 1 9}$ & $\mathbf{2 0 1 8}$ & $\mathbf{2 0 1 9}$ \\
\hline CFD & 43.56 & 45.31 & 23.97 & 24.63 & 32.47 & 30.07 \\
\hline NWFD & 35.23 & 36.31 & 36.53 & 36.59 & 28.24 & 27.10 \\
\hline NCFD & 32.16 & 34.20 & 42.84 & 42.32 & 25.00 & 23.48 \\
\hline SFD & 27.72 & 26.72 & 44.38 & 43.72 & 27.90 & 29.56 \\
\hline VFD & 36.49 & 36.33 & 33.59 & 33.10 & 29.92 & 30.57 \\
\hline UFD & 35.16 & 38.26 & 21.09 & 20.87 & 43.75 & 40.87 \\
\hline Siberian Federal District & 27.32 & 28.92 & 35.31 & 34.09 & 37.37 & 36.99 \\
\hline FEFD & 51.35 & 43.66 & 22.97 & 29.58 & 25.68 & 26.76 \\
\hline
\end{tabular}

Source: compiled by the authors

Table 3 shows that:

- the largest share of employees with higher education was observed in the Central Federal District, and the smallest - in the Siberian Federal District;

- the largest share of employees with secondary general education was observed in the Southern Federal District, and the smallest - in the Ural Federal District;

- the largest share of employees with secondary vocational education was observed in the Urals Federal District, and the smallest in the North Caucasus Federal District.

Table 4. Increases in the proportions of employees of the considered FGBU Department of Land Reclamation with higher, secondary general and secondary vocational education in federal districts for $2018-2019, \%$.

\begin{tabular}{|c|c|c|c|}
\hline \multirow{2}{*}{ FD } & \multicolumn{3}{|c|}{ Education } \\
\cline { 2 - 4 } & higher & secondary & secondary professional \\
\hline CFD & 1.74 & 0.65 & -2.40 \\
\hline NWFD & 1.08 & 0.06 & -1.14 \\
\hline NCFD & 2.04 & -0.52 & -1.52 \\
\hline SFD & -1.00 & -0.66 & 1.65 \\
\hline VFD & -0.16 & -0.48 & 0.65 \\
\hline
\end{tabular}




\begin{tabular}{|c|c|c|c|}
\hline \multirow{2}{*}{ FD } & \multicolumn{3}{|c|}{ Education } \\
\cline { 2 - 4 } & \multirow{2}{*}{ higher } & secondary & secondary professional \\
\hline UFD & 3.10 & -0.22 & -2.88 \\
\hline Siberian Federal District & 1.60 & -1.23 & -0.38 \\
\hline FEFD & -7.69 & 6.60 & 1.08 \\
\hline
\end{tabular}

Source: compiled by the authors

Table 4 shows that in 2019:

- in the Central Federal District and Northwestern Federal District, the proportion of employees with higher and secondary general education increased, while the proportion of employees with secondary vocational education decreased;

- in the North Caucasus Federal District the proportion of employees with higher education has increased, while the proportion of employees with secondary general and secondary vocational education has decreased;

- in the Southern Federal District and the Volga Federal District, the proportion of employees with higher and secondary general education decreased, while the proportion of employees with secondary vocational education increased;

- in the Ural Federal District and the Siberian Federal District the proportion of employees with higher education has increased, while the proportion of employees with secondary general and secondary vocational education has decreased;

- in the Far Eastern Federal District the share of employees with higher education has decreased, while the shares of employees with secondary general and secondary vocational education have increased.

Another criterion for studying the potential of the labor force in the land reclamation industry was the analysis of the professional growth of employees of the Federal State Budgetary Institution of the Department of Land Reclamation of the Ministry of Agriculture of the Russian Federation by federal districts for 2018-2019.

The study showed that the largest number of FSBI employees who underwent training in the additional vocational education system in 2018-2019 observed in the Southern Federal District, and the smallest in the Urals Federal District. Herewith, the overwhelming number of employees studied under the programs of additional vocational education up to 250 hours and in areas directly unrelated to agriculture, land reclamation, economics and management. This situation indicates a decrease in the efficiency of industry-specific additional professional training and retraining. In this vein, the work calculated the absolute and relative indicators of the growth in the number of employees of the FSBI Department of Land Reclamation who were trained in the additional vocational education system in federal districts for 2019 in comparison with the level of 2018.

\section{Conclusion}

Since the most indicative are relative data, here are the results:

- tendencies of change in the number of employees of the FSBI Department of Land Reclamation who completed training in the additional vocational education system in federal districts for 2018-2019. are of a multidirectional nature and are not linked to the existing need for advanced training and retraining in the RF Federal District;

- especially alarming is the revealed regularity in the decrease in the increase in the percentage of employees who have been trained in the additional vocational education system in the direction of land reclamation, which is typical for all FDs except for the Siberian Federal District. 
The revealed situation, pursuant to the studied and presented indicators of staffing of the Department of Land Reclamation, indicates serious threats associated with the development of industry staff potential. This result is largely a reflection of the all-Russian picture that has developed on the national labor market.

Pursuant to the study results, as some recommendations for the development of the potential of the land reclamation workforce, the authors consider it necessary to:

- pay special attention to FDs and groups of industry personnel, which show negative relationships between the age structure of employees and groups that have received vocational education, as well as groups of personnel in FDs with unobservable regularities in the formation of labor potential;

- it is important to consider the specific features of catch-up education and psychophysiological characteristics of perception, education of the adult population, the prevailing age groups studying at the Department of Land Reclamation (for most FDs, these are 40-49 years old, 50-59 years old and over 64 years old);

- to develop and systematically implement monitoring of staffing for the Department of Land Reclamation as the main technology for building the potential of the workforce in the industry. This monitoring will make it possible to form a unified personnel database of the Land Reclamation Department and its systematic updating.

The practical significance lies in the possibility of applying the results obtained for:

- management of ameliorative development of the territories of the Russian Federation;

- development and implementation of recommendations to enhance the efficiency of the development of ameliorated agriculture in the Russian Federation (including in the RF federal disctricts);

- development of recommendations for advanced training and retraining of personnel in land reclamation;

- formation of the concept of forecasting the needs of the Department of Land Reclamation in qualified personnel;

- application in the process of studying the training courses "Economics of Irrigated Agriculture", "Economics of Agriculture" in the system of higher professional and additional professional education.

The development and implementation of recommendations will help to enhance the efficiency of the process of managing the potential of ameliorated agriculture in the Russian Federation.

\section{References}

1. Strategy for the economic development of land reclamation. http://www.rosniipm.ru/nauchnaja-dejatelnos/strategiya-ehkonomicheskogo-razvitiyamelioracii

2. T.I. Gulyaeva, E.V. Buraeva, O. Yu. Grishaeva, Econ. analysis: theor. etc. 14(31), 26 (2015)

3. M.L. Vartanova, Ros. pred. 5, 869 (2015)

4. A.V. Kozlov, Staffing of agriculture in the conditions of innovative development, dis. for the degree of Doctor of Economics (M., 2015)

5. 5. I. N. Primishev, S.G. Cheremisina, S.S. Skaranik, Ros. pred. 19(5), 1597 (2018)

6. M.V. Noskova, Bulletin of Altai State Agrarian University, 4 (2010)

7. I.A. Khlusova, V.N. Khlusov, Econ. Issled. 2, 5 (2017)

8. Study of the influence of the structure of personnel in irrigated agriculture on the system of advanced training and retraining of personnel: report on research. FGBNU VNII 
"Raduga"; Ugryumova A.A .; performed by: Zamakhovsky M.P., Pautova L.E. et al., 491 p. (Kolomna, 2019). No. GR R\&D AAAA-A19-119090290014-6.

9. Conduct research on the impact of the state reclamation infrastructure on the socioeconomic development of the territory of the Russian Federation: report on research. FGBNU VNII "Raduga"; Ugryumova A.A .; performed by: Zamakhovsky M.P., Pautova L.E., Grishaeva O.Yu. et al., 469 p. (Kolomna, 2020). No. GR AAAA-A20120041490018-0.

10. A.A. Ugryumova, L.E. Pautova, S.I. Ashmarina, V.V. Mantulenko (eds), Digital Economy and the New Labor Market: Jobs, Competences and Innovative HR Technologies. IPM 2020. Lecture Notes in Networks and Systems, 161 (Springer, Cham., 2020). https://doi.org/10.1007/978-3-030-60926-9_94

11. Reclamation complex of the Russian Federation: inform. edition. M.: FGBNU "Rosinformagrotech", 304 p. (2020)

12. G.V. Olgarenko, S.M. Vasiliev, G.T. Balakay, Concept of the state program "Restoration and development of the reclamation complex of the Russian Federation for the period 2020-2030", 129 p. (Novocherkassk: RosNIIPM, 2019)

13. O.R. Skorokhodova, Econ. and Management in the 21st Century: Development Trends 24, 67 (2015)

14. E.V. Dankova, N.I. Osipenko, Vestn. Acad., 3, 91 (2013)

15. A.M. Kalachev, Human Resources: Problems of Innovative Development and Use: Collection of Scientific Papers for the 40th Anniversary of the Faculty of Economics of the KemSU. Kemerovo 3, 90 (2014)

16. A. Ya. Kibanov, Man. personnel and intel. res. in Russia 3 (1(10)), 5 (2014) https://doi.org/10.12737/2619

17. 17. E.V. Senchenko, Econ. and Management in the 21 st Century: Development Trends 22, 71 (2015)

18. L.R. Shagivaliev, Vestn. agr. Science 61 (4), 65 (2016)

19. Educational challenges and drivers of irrigated agriculture personnel in the Russian Federation: monograph, col. authors; ed. G.V. Olgarenko, A.A. Gloomova, Moscow: RUSAYNS, 255 p. (2020)

20. G.V., Olgarenko, A.A. Ugryumova, T.A. Kapustina, M.P. Zamakhovski, L.E. Pautova, IJM 6(7), 28 (2015)

21. L.R. Shagivaliev, Vestn. Kursk. State agricultural acad. 6, 56 (2017)

22. A.Y. Anisimov, A.S. Obukhova, Y.V. Aleksakhina, A.V. Zhaglovskaya, A.A. Kudra, IJEP 11(2), 442 (2017)

23. A.K. Khodzhaevich, K.S. Davlyatovich, M.A. Yuldashevich, IJITEE, 8(9) Sp. Iss. 3, 169 (2019)

24. M. Ghasemi, I. Keykha, A.A. Nezhad, H.M. Niya, Fundamental and applied res. in the modern world 12-5, 152 (2015)

25. V.I. Trukhachev, I.Y. Sklyarov, J.M. Sklyarova, L.A. Latysheva, H.N. Lapina, IJFI 6, 33 (2016) 